\title{
Amidated fish ghrelin: purification, cDNA cloning in the Japanese eel and its biological activity
}

\author{
H Kaiya ${ }^{1}$, M Kojima ${ }^{1,3}$, H Hosoda ${ }^{1}$, L G Riley², T Hirano², \\ E G Grau ${ }^{2}$ and K Kangawa ${ }^{1}$ \\ ${ }^{1}$ Department of Biochemistry, National Cardiovascular Center Research Institute, 5-7-1 Fujishirodai, Suita, Osaka 565-8565, Japan \\ ${ }^{2}$ Hawaii Institute of Marine Biology, University of Hawaii, Kaneohe, Hawaii 96744, USA \\ ${ }^{3}$ Division of Molecular Genetics, Institute of Life Science, Kurume University, 2432-3 Aikawa-machi, Kurume, Fukuoka 839-0861, Japan \\ (Requests for offprints should be addressed to H Kaiya; Email: kaiya@ri.ncvc.go.jp)
}

\begin{abstract}
We purified ghrelin from stomach extracts of a teleost fish, the Japanese eel (Anguilla japonica) and found that it contained an amide structure at the C-terminal end. Two molecular forms of ghrelin with 21 amino acids were identified by cDNA and mass spectrometric analyses: eel ghrelin-21, GSS(O-n-octanoyl)FLSPSQRPQGKDKKPP RV-amide and eel ghrelin-21-C10, GSS(O-n-decanoyl) FLSPSQRPQGKDKKPPRV-amide. Northern blot and RT-PCR analyses revealed high gene expression in the stomach. Low levels of expression were found only in the brain, intestines, kidney and head kidney by RT-PCR analysis. Eel ghrelin-21 increased plasma growth hormone
\end{abstract}

$(\mathrm{GH})$ concentrations in rats after intravenous injection; the potency was similar to that of rat ghrelin. We also examined the effect of eel ghrelin on the secretion of GH and prolactin (PRL) from organ-cultured tilapia pituitary. Eel ghrelin-21 at a dose of $0 \cdot 1 \mathrm{nM}$ stimulated the release of $\mathrm{GH}$ and PRL, indicating that ghrelin acts directly on the pituitary. The present study revealed that ghrelin is present in fish stomach and has the ability to stimulate the secretion of GH from fish pituitary. A novel regulatory pathway of GH secretion by gastric ghrelin seems to be conserved from fish to human.

Journal of Endocrinology (2003) 176, 415-423

\section{Introduction}

In mammals, the secretion of growth hormone $(\mathrm{GH})$ is regulated primarily by growth hormone-releasing hormone $(\mathrm{GHRH})$ and somatostatin released from the hypothalamus (Bluet-Pajot et al. 1998). In fish, various hypothalamic peptides such as GHRH, gonadotropinreleasing hormone $(\mathrm{GnRH})$, thyrotropin-releasing hormone (TRH), neuropeptide Y (NPY), cholecystokinin (CCK), pituitary adenylate cyclase activating polypeptide and corticotropin-releasing hormone have been shown to be involved in GH release in different teleost species (Peng \& Peter 1997, Montero et al. 2000), but species differences have been found in their effects. GHRH stimulates the release of GH in goldfish, rainbow trout and tilapia, but has only a weak effect in salmon (Parker et al. 1997). GHRH does not show any effect on GH secretion in the eel (Montero et al. 1998, Rousseau et al. 1999). GnRH stimulates the release of $\mathrm{GH}$ in goldfish, common carp and tilapia, but no effect is seen in the trout (Blaise et al. 1995), catfish (Bosma et al. 1997) or eel (Rousseau et al. 1999). $\mathrm{TRH}$ induces the release of $\mathrm{GH}$ in the goldfish and common carp, but not in the tilapia (Melamed et al. 1995) or eel (Rousseau et al. 1999). NPY and CCK stimulate the release of GH in the goldfish, but not in the eel (Rousseau et al. 1999). There is no consensus regarding the identity of a common regulator of GH release in fish.

We recently identified an endogenous ligand for the orphan G-protein-coupled growth hormone secretagogue receptor (GHS-R) (Kojima et al. 1999). This novel molecule, a 28-amino acid peptide named 'ghrelin', possesses a unique serine residue at the $\mathrm{N}$-terminal position $3\left(\mathrm{Ser}^{3}\right)$ with an acyl modification by $n$-octanoic acid. This acylation is essential for biological activity (Kojima et al. 1999) and receptor binding (Muccioli et al. 2001). Ghrelin exhibits potent GH-releasing activity in the rat in vivo and in vitro. However, little is known about its structure or function in non-mammalian vertebrates. Recently, we purified ghrelin and cloned its cDNA in the bullfrog and chicken (Kaiya et al. 2001, 2002). Both species of ghrelin possess an $n$-octanoylated third residue, as seen in mammalian ghrelins. In the bullfrog, however, the third amino acid is a threonine, not a serine. Bullfrog ghrelin stimulates secretion of $\mathrm{GH}$ and prolactin (PRL) in cultured adenohypophyseal cells, but only a weak effect on release of $\mathrm{GH}$ was observed in the rat in vivo. In contrast, 
chicken ghrelin, which like mammals possesses a $\mathrm{Ser}^{3}$, is capable of stimulating the release of $\mathrm{GH}$ in both chicken and rat in vivo.

In fish, three species of receptor gene belonging to the GHS-R family have been identified in the pufferfish (Palyha et al. 2000). A recent in vivo study in tilapia demonstrated that plasma $\mathrm{GH}$ concentrations were increased by a growth hormone secretagogue (GHS), KP-102 (Shepherd et al. 2000). Furthermore, release of $\mathrm{GH}$ from the tilapia pituitary in vitro is stimulated by rat ghrelin (Riley et al. 2002). These results strongly suggest that a ghrelin-GHS-R system may exist and have a role in the release of $\mathrm{GH}$ in fish. Recently, Unniappan et al. (2002) have identified fish ghrelin cDNA and gene structure from goldfish brain and intestine. Goldfish ghrelin had some unique structures that have not been seen in other ghrelins: the C-terminal amide structure and a second amino acid substitution to threonine from serine.

In the present study, we purified ghrelin peptide from the stomach of the Japanese eel, Anguilla japonica, and determined cDNA encoding the precursor protein. Because this species belongs to the group of Elopomorphs considered to be close to the origin of teleosts, we aimed to obtain information about the ancestral structure of ghrelin. We report here that eel ghrelin possesses the C-terminal amide structure, as seen in goldfish ghrelin. In addition, eel ghrelin stimulates the release of $\mathrm{GH}$ in the rat in vivo and the release of $\mathrm{GH}$ and $\mathrm{PRL}$ in the tilapia in vitro.

\section{Materials and Methods}

\section{Purification of eel ghrelin from stomach tissue}

During the purification process, ghrelin activity was followed by measuring changes in intracellular calcium concentration $\left(\left[\mathrm{Ca}^{2+}\right]_{i}\right)$ using a fluorimetric imaging plate reader (FLIPR; Molecular Devices, Sunnyvale, CA, USA) in a cell line expressing rat GHS-R (Chinese hamster ovary (CHO)-GHSR62) as described previously (Kojima et al. 1999, Kaiya et al. 2001, 2002). Crude acetic acid $(\mathrm{AcOH})$ extracts prepared from fresh eel stomach $(231.7 \mathrm{~g})$ were treated with cold acetone at a final concentration of $66 \%$. After centrifugation $(13600 \mathrm{~g}$ for $30 \mathrm{~min}$ ), the supernatant was treated with two Sep-Pak Vac 35 cc (10 g) C18 cartridges (Waters Corp., Milford, MA, USA), to enrich the peptide component. The resulting peptide-rich fraction was subjected to cationexchange chromatography (SP-Sephadex C-25, $\mathrm{H}^{+}$-form, Amersham Pharmacia Biotech). Successive elution of $1 \mathrm{M}$ $\mathrm{AcOH}, 2 \mathrm{M}$ pyridine and $2 \mathrm{M}$ pyridine- $\mathrm{AcOH}(\mathrm{pH} 5 \cdot 0$ ) yielded three fractions: SP-I, SP-II, and SP-III respectively. The basic peptide-enriched SP-III fraction was subjected to a Sephadex G-50 column (fine grade, $2.9 \times 144.5 \mathrm{~cm}$, Amersham Pharmacia Biotech) at flow rate of $15 \mathrm{ml} / \mathrm{h}$. The eluate was collected in $15-\mathrm{ml}$ fractions. A $15-\mathrm{mg}$ tissue equivalent of each fraction was assayed by FLIPR. The active fractions were subjected to carboxymethyl cation-exchange HPLC (TSKgel CM2SW, $4.6 \times 250 \mathrm{~mm}$, Tosoh, Tokyo, Japan) at a flow rate of $1 \mathrm{ml} / \mathrm{min}$. A two-step gradient profile was made from solvent A (10 mM ammonium formate $(\mathrm{pH} 4 \cdot 8) / 10 \%$ acetonitrile $(\mathrm{ACN})$ ) to $25 \%$ solvent $\mathrm{B}$ (1 M ammonium formate ( $\mathrm{pH} 4 \cdot 8) / 10 \% \mathrm{ACN})$ ) for $10 \mathrm{~min}$ and then to $55 \%$ solvent B for $90 \mathrm{~min}$. The eluate was collected in $1-\mathrm{ml}$ fractions. A $20-\mathrm{mg}$ tissue equivalent of each fraction was assayed by FLIPR. One-tenth of the active fractions (approximately $23 \mathrm{~g}$ tissue equivalent) were desalted by a Sep-Pak Light C18 cartridge (Waters Corp.). The lyophilized sample was dissolved in $100 \mathrm{mM}$ phosphate buffer ( $\mathrm{pH} 7 \cdot 4)$ and applied to an anti-rat ghrelin(1-11) immunoglobulin $G$ (IgG) immuno-affinity column $(50 \mu \mathrm{l}$ gel volume) to purify ghrelin-immunoreactive substances. Adsorbed substances were eluted with $0.5 \mathrm{ml}$ of a $60 \%$ ACN- $0 \cdot 1 \%$ trifluoroacetic acid (TFA) solution and then separated by reverse-phase (RP) HPLC using a $\mu$ Bondasphare C18 column $(3.9 \times 150 \mathrm{~mm}$, Waters Corp.) at a flow rate of $1 \mathrm{ml} / \mathrm{min}$ under a linear gradient from $10 \%$ to $60 \%$ ACN- $0 \cdot 1 \%$ TFA for $40 \mathrm{~min}$. The eluate was collected in $0.5 \mathrm{ml}$-fractions. Active fractions were further purified on a $\mu$ Bondasphare C18 column $(2.1 \times 150 \mathrm{~mm}$, Waters Corp. $)$ at a flow rate of $0.2 \mathrm{ml} /$ min under a linear gradient from $10 \%$ to $60 \% \mathrm{ACN}-0 \cdot 1 \%$ TFA for $40 \mathrm{~min}$. The eluate corresponding to each absorbance peak was collected. To analyze peptide sequences, $10 \mathrm{pmol}$ of the purified peptide was applied to a protein sequencer (model 494, PE Applied Biosystems, Foster City, CA, USA). To analyze amino acid composition, 50 pmol of the purified peptide was applied to an amino acid analyzer (model L-8500A, Hitachi, Tokyo, Japan). The molecular weight of the purified peptide was determined using MALDI-TOF mass spectrometry (Voyager systems, PE Applied Biosystems).

\section{$3^{\prime}$-Rapid amplification of $c D N A$ ends PCR}

Eel ghrelin cDNA was cloned from an eel stomach cDNA library constructed with $3 \mu \mathrm{g}$ poly(A) ${ }^{+}$RNA using an eel ghrelin cDNA fragment prepared by $3^{\prime}$-rapid amplification of cDNA ends (RACE) PCR for a probe. Poly(A) ${ }^{+}$ RNA was isolated from total RNA using a mRNA purification kit (TaKaRa, Kyoto, Japan). First-strand cDNA was synthesized from $500 \mathrm{ng}$ poly(A) ${ }^{+}$RNA using an oligo(dT)-containing adapter primer supplied by the 3'-RACE system (Invitrogen Life Technologies). The reaction mixture was purified with a Wizard PCR preps DNA purification system (Promega Corp.) and eluted in $50 \mu \mathrm{l}$ sterilized water. One-tenth of this purified cDNA served as a template for PCR using four degenerate sense-primers, based on the N-terminal seven amino acid sequence conserved in mammalian ghrelins (GSSFLSP): S1, 5'-GGGTCGAGYTTCTTRTCNCC-3'; S2, 5'-GG GTCGAGYTTCTTRAGYCC-3'; S3， 5'-GGGTCGA 
GYTTCCTNTCNCC-3'; S4, 5'-GGGTCGAGYTTCC TNAGYCC-3'. Primary PCR was performed with these degenerate sense-primers, a $3^{\prime}$-universal amplification primer (UAP) supplied with a 3'-RACE kit, and Ex Taq DNA polymerase (TaKaRa). Sequences were amplified at $94{ }^{\circ} \mathrm{C}$ for $1 \mathrm{~min}$, with 35 subsequent cycles of $94{ }^{\circ} \mathrm{C}$ for $30 \mathrm{~s}, 58^{\circ} \mathrm{C}$ for $30 \mathrm{~s}$ and $72^{\circ} \mathrm{C}$ for $1 \mathrm{~min}$. Next, nested PCR was performed with one-tenth of the purified primary PCR product, a gene-specific sense-primer $\left(5^{\prime}-\mathrm{CCC}\right.$ TCACAGAGACCGCAGGG-3', nucleotides 153-172), based on the amino acid sequence of the purified eel ghrelin(7-13), and UAP under the following conditions: $94{ }^{\circ} \mathrm{C}$ for $1 \mathrm{~min}$, and 30 subsequent cycles of $94^{\circ} \mathrm{C}$ for $30 \mathrm{~s}, 52^{\circ} \mathrm{C}$ for $30 \mathrm{~s}$ and $72{ }^{\circ} \mathrm{C}$ for $1 \mathrm{~min}$. The candidate product was subcloned using a TOPO TA cloning kit (pCRII-TOPO vector, Invitrogen). The nucleotide sequence was determined with a DNA sequencer (model 373, PE Applied Biosystems), according to the Thermosequence II dye terminator cycle sequencing kit procedure (Amersham Pharmacia Biotech). An approximately 400-bp EcoRI-digested fragment of eel ghrelin cDNA was used as a screening probe for the cDNA library described below.

\section{cDNA cloning}

Double-stranded cDNA was synthesized from $3 \mu \mathrm{g}$ stomach poly(A) ${ }^{+}$RNA using a cDNA synthesis kit (Amersham Pharmacia Biotech) with SuperScript II reverse transcriptase (Invitrogen). Complementary DNA was ligated to adapters. The cDNA was size-selected on a Sephacryl S-500 HR column (Invitrogen) and ligated into the EcoRI site of the ZAP II vector. The titer of the cDNA library was $8.9 \times 10^{5} \mathrm{pfu} / \mathrm{ml}$. Phage DNA (40 000 $\mathrm{pfu} /$ plate $\times 8$ plates) was transferred onto nylon membranes (Biodyne B, Pall East Hills, NY, USA), and hybridized with an EcoRI-digested eel ghrelin cDNA fragment labeled with $\left[\alpha-{ }^{32} \mathrm{P}\right] \mathrm{dCTP}$ for $24 \mathrm{~h}$ at $37^{\circ} \mathrm{C}$ in a hybridization buffer $[5 \times \operatorname{SSPE}(750 \mathrm{mM} \mathrm{NaCl}, 50 \mathrm{mM}$ $\mathrm{NaH}_{2} \mathrm{PO}_{4}$, and $5 \mathrm{mM}$ EDTA, pH 7.4), $5 \times$ Denhardt's solution, $50 \%$ formamide, $0.5 \%$ SDS and $100 \mathrm{ng} / \mathrm{ml}$ calf thymus DNA]. Hybridized membranes were washed twice with $2 \times \mathrm{SSC}-0 \cdot 1 \% \mathrm{SDS}$ at $55^{\circ} \mathrm{C}$ for $30 \mathrm{~min}$ and then subjected to autoradiography on X-ray films (Kodak, Tokyo, Japan) at $-80{ }^{\circ} \mathrm{C}$ for $24 \mathrm{~h}$. Eight phages that gave positive plaques were isolated in the secondary screening, and these phages were infected to XL 1-Blue $\mathrm{MRF}^{\prime}$ with a helper phage. After in vivo excision with SOLR as a host strain (Stratagene, LaJolla, CA, USA), a resultant plasmid containing full-length eel ghrelin cDNA was analyzed.

\section{Gene expression analyses}

Northern blot analysis was conducted using $2 \mu \mathrm{g}$ poly(A) ${ }^{+}$ RNA prepared from nine eel tissues: whole brain, heart, stomach, anterior, middle and posterior intestine, body kidney, head kidney and gill. RNA was electrophoresed on a $1 \%$ agarose-formamide gel for $2 \mathrm{~h}$ at $50 \mathrm{~V}$ and then transferred onto a nylon membrane (Zeta-probe, BioRad, Hercules, CA, USA). ${ }^{32} \mathrm{P}$-Labeled full-length eel ghrelin cDNA was hybridized to the membrane. The hybridization and wash conditions followed the procedure as described above. Membrane was exposed to an Image plate (Fuji photo film Co., Ltd, Kanagawa, Japan) for $3 \mathrm{~h}$. The intensity of the plate was scanned using a BAS-5000 bioimaging analyzer (Fuji photo film Co., Ltd).

Reverse transcription-PCR analysis was conducted on cDNA from the same nine tissues. Template cDNA was made from $50 \mathrm{ng}$ poly $(\mathrm{A})^{+}$RNA using SuperScript II reverse transcriptase. One-tenth of the cDNA was used as a template. PCR was performed using HotStarTaq Master Mix (Qiagen $\mathrm{GmbH}$ ). The 20- $\mu$ l reaction mixture contained $4 \mu \mathrm{l}$ cDNA solution (10 ng mRNA equivalent), $1 \mu \mathrm{l} 10 \mu \mathrm{M}$ sense-primer (eel ghrelin-full-s2; 5'-TAC ATCATCCTGCTGGTCTGC-3', nucleotides 81-101) and $1 \mu \mathrm{l} 10 \mu \mathrm{M}$ antisense-primer (eel ghrelin-full-as1; 5'-TTGGCAGGTGTGTCCATCAGC-3', nucleotides 365-385). The amplification reaction was performed at $95^{\circ} \mathrm{C}$ for $15 \mathrm{~min}$, with subsequent 30 or 35 cycles of $94{ }^{\circ} \mathrm{C}$ for $30 \mathrm{~s}, 56{ }^{\circ} \mathrm{C}$ for $30 \mathrm{~s}, 72{ }^{\circ} \mathrm{C}$ for $1 \mathrm{~min}$, and final extension for $3 \mathrm{~min}$ at $72{ }^{\circ} \mathrm{C}$. Resultant PCR products (305-bp) were electrophoresed on a $2 \%$ agarose gel containing ethidium bromide.

In vivo effect of eel ghrelin on release of $G H$ in the rat

Eel ghrelin was synthesized at the Suntory Institute for Medicinal Research \& Development as described previously (Matsumoto et al. 2001). Male Sprague-Dawley rats weighing $250-280 \mathrm{~g}$ were cannulated in the femoral artery and vein under pentobarbital sodium anesthesia. After untreated blood had been sampled (time 0), $2 \mathrm{nmol} /$ $250 \mathrm{~g}$ body weight of either synthetic eel ghrelin-21 or rat ghrelin was injected into the femoral vein. Blood $(150 \mu \mathrm{l})$ was collected from the femoral artery in a syringe containing EDTA (1 mg/ml blood) at 5, 10, 15, 20, 30 and 60 min after injection. GH concentration in plasma was measured using a rat GH enzyme immunoassay kit (Biotrak, Amersham Pharmacia Biotech). Data were analyzed by two-way analysis of variance (ANOVA) to evaluate the effects of time or of time compared with ghrelin species.

In vitro effects of eel ghrelin on the secretion of $\mathrm{GH}$ and $P R L$ in the tilapia

Mozambique tilapia, Oreochromis mossambicus, weighing 50-200 g, were used. They were maintained in fresh water $\left(25 \pm 2{ }^{\circ} \mathrm{C}\right)$ and fed twice daily. Whole pituitaries were removed and pre-incubated in a 96-well plate for $18-20 \mathrm{~h}$ at $27^{\circ} \mathrm{C}$ in $100 \mu \mathrm{l}$ isosmotic bicarbonateRinger solution (330 $\mathrm{mOsmol})$ with essential additives as 
(a)

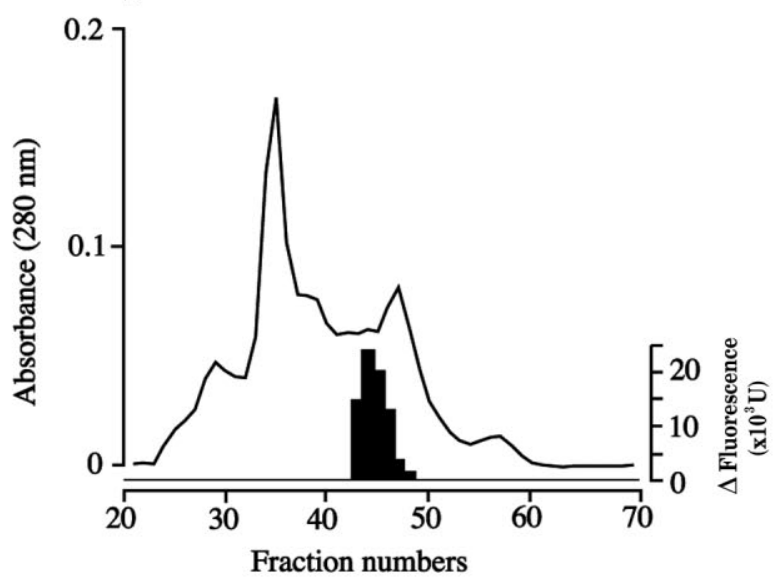

(b)

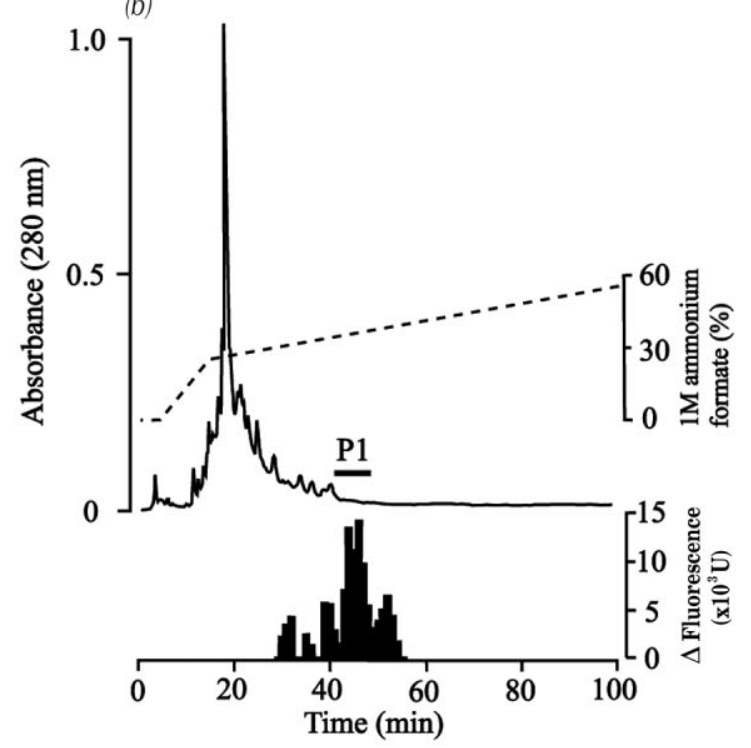

(c)

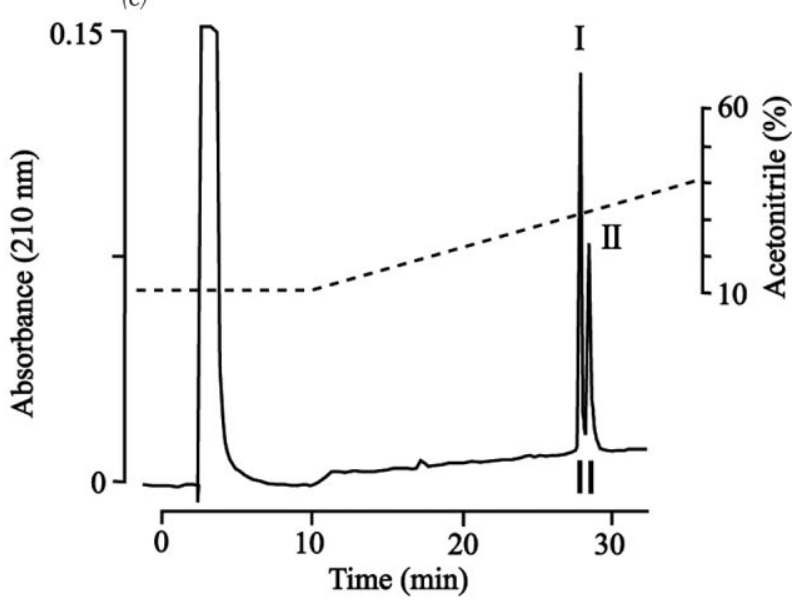

described previously (Wigham et al. 1977), supplemented with $0.025 \mu \mathrm{g} / \mathrm{ml}$ gentamicin. The pre-incubation medium was removed and replaced with fresh medium $(100 \mu \mathrm{l})$ containing increasing concentrations of eel ghrelin-21 (0, 0·1, 1 and $10 \mathrm{nM})$. Medium samples were removed at 2, 4 and $8 \mathrm{~h}$, and replaced with fresh medium containing appropriate concentrations of eel ghrelin. Medium samples were stored at $-20{ }^{\circ} \mathrm{C}$ until required for analysis for $\mathrm{GH}$ and PRL $\left(\mathrm{PRL}_{188}\right)$ by homologous radioimmunoassay (Ayson et al. 1993) as modified by Yada et al. (1994). Release of GH and PRL was expressed as ng/ $100 \mathrm{~g}$ body weight, because significant correlation was observed between the amounts of hormone released from the pituitary and body weight (Eckert et al. 2002). Group comparisons were performed using one-way ANOVA, followed by the least significant test or by Mann-Whitney $U$-test for each time point. Correlation was determined using the Pearson correlation test. Calculations were performed using a computer program, Statistica (StatSoft, Tulsa, OK, USA).

\section{Results}

Purification and structural determination of eel ghrelin

The SP-III fraction (51·3-mg protein) in which ghrelin activity was detected by the FLIPR assay was separated by Sephadex G-50 gel-permeation chromatography (Fig. 1a). Ghrelin activity was eluted in fractions 43-48, which correspond to a molecular weight of approximately 3000 Da. Active fractions 43-47 were subjected to carboxymethyl cation-exchange HPLC (Fig. 1b). Ghrelin activity was observed in 25 consecutive fractions from 29 to 53 . Fractions $42-47$, showing high activity (P1), were purified by an anti-rat ghrelin(1-11) IgG immuno-affinity column. Two peaks (I and II) containing high ghrelin activity were isolated by secondary RP-HPLC after the immuno-affinity chromatography (Fig. 1c). The yields of peak I and II peptides were estimated to be approximately 230 and 180 pmol respectively. Amino acid sequences of both peptides were identical: GSXFLSPSQRPQGKD KKPPR (X, unidentified). The unidentified X residue at position 3 was predicted to contain an acyl modification, as seen in other ghrelins. Amino acid composition analysis revealed that one more serine (Ser) and one more valine (Val) were present in the purified peptides (data not

Figure 1 Purification of eel ghrelin from eel stomach extract. (a) Sephadex G-50 gel-permeation chromatography of the SP-III fraction. (b) Carboxymethyl cation-exchange HPLC ( $\mathrm{pH} 4.8)$ of the active fraction from gel-permeation chromatography. The active fraction (P1) was then purified by anti-rat ghrelin(1-11) IgG immuno-affinity chromatography. (c) Secondary RP-HPLC of immuno-affinity chromatography binding peptides. Peaks I and II were isolated. Black bars indicate the changes in fluorescence in $\left[\mathrm{Ca}^{2}\right]_{i}$ in CHO-GHSR62 cells. 


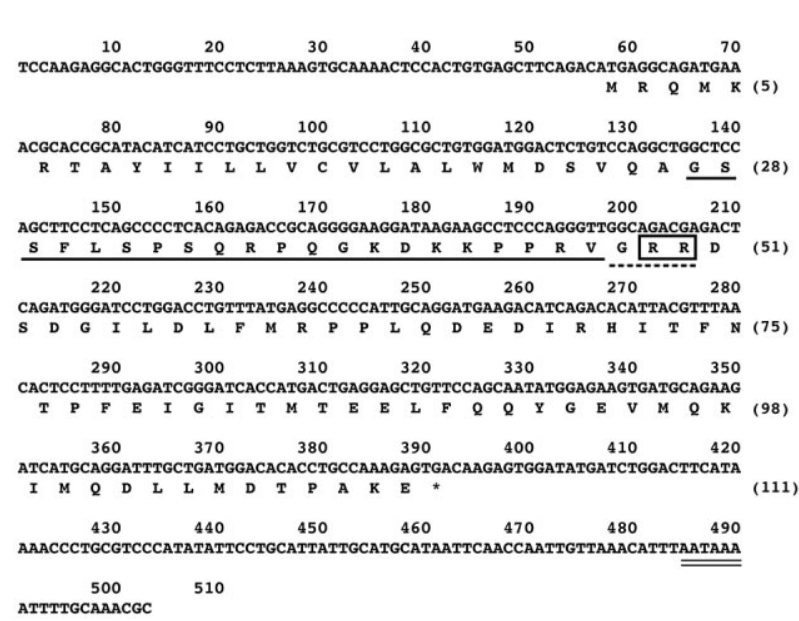

Figure 2 Nucleotide sequences and deduced amino acid sequence of the eel ghrelin. The eel ghrelin cDNA contains 503 nucleotides. Prepro-ghrelin is composed of 111 amino acids (parentheses at right). The mature sequence of eel ghrelin is underlined and a typical dibasic processing sequence is boxed. Dotted line, C-terminal amidation signal; double underline, polyadenylation signal (AATAAA).

shown). From peptide sequence and amino acid composition analyses, we predicted that the unidentified $\mathrm{X}$ residue is a Ser from the homology of mammalian ghrelins, and that the C-terminal end of these two peptides may contain an additional Val residue. Thus the expected eel ghrelin comprised 21 amino acids with the following sequence: GSSFLSPSQRPQGKDKKPPRV.

To determine the complete sequence, we isolated its cDNA encoding precursor protein from an eel stomach cDNA library. The isolated full-length eel cDNA was 503 bp long, containing a 56 bp $5^{\prime}$-untranslated region (UTR), a 336-bp coding region and a $110 \mathrm{bp} 3^{\prime}$-UTR (Fig. 2). Although two ATG codons are present in the 5'-UTR, it was predicted that the first ATG codons (nucleotides 57-59) encode the initial methionine by Kozak's rule (A or GnnATGA or G) and by homology of other fish ghrelin precursor sequences (data not shown). A typical polyadenylation signal (AATAAA) was identified in the $3^{\prime}-\mathrm{UTR}$. The deduced amino acid sequence of the coding region indicated that the eel ghrelin precursor is 111-amino acids long (Fig. 2). The unidentified third amino acid and the C-terminal end of amino acid were determined to be Ser and Val, respectively, as predicted by the amino acid composition analysis. A typical amidation signal, Gly-Arg-Arg, was followed at the C-terminal Val of the mature peptide. Thus eel ghrelin is likely to be terminated with Val-amide.

We examined the molecular weight of the purified eel ghrelin isoforms (peak I and II) by MALDI-TOF mass spectrometry. Molecular weights of peak I and II were $2421.7 \mathrm{Da}$ and $2449.2 \mathrm{Da}$ respectively; the values are approximately 126 and 154 mass units greater than the

\section{- Peak I (eel ghrelin-21):}

$$
\begin{aligned}
& \mathrm{O}=\underset{0}{\mathrm{C}}-\left(\mathrm{CH}_{2}\right)_{6}-\mathrm{CH}_{3} \\
& \text { GSSFLSPSQRPQGKDKKPPRV-amide }
\end{aligned}
$$

\section{- Peak II (eel ghrelin-21-C10):}

$$
\begin{aligned}
& \mathrm{O}=\mathrm{C}-\left(\mathrm{CH}_{2}\right)_{8}-\mathrm{CH}_{3} \\
& \stackrel{O}{1} \\
& \stackrel{\text { GSSFLSPSQRPQGKDKKPPRV-amide }}{ }
\end{aligned}
$$

Figure 3 Structure of eel ghrelin. The identity of the third serine residue $\left(\mathrm{Ser}^{3}\right)$ was determined by cDNA analysis. The modifications of $\mathrm{Ser}^{3}$ with $n$-octanoic acid in peak I and with $n$-decanoic acid in peak II were determined by mass spectrometric analysis.

Eel
Goldfish-12
Goldfish-19
Bullfrog
Chicken
Human
Rat, Mouse
Bovine
Pig
Dog

$\begin{array}{ll}\text { GSSFLSPS-QRPQG-KD-KKP-----PRV } & (21) \\ \text { GTSFLSPA-QKPQ------------ } & (12) \\ \text { GTSFLSPA-QKPQGR----RP-----PRM } & (19) \\ \text { GLTFLSPADMQKIAERQSQNKLRH-GNMN } & (28) \\ \text { GSSFLSPTYKNIQQQKDTRKPTARL--H- } & (26) \\ \text { GSSFLSPEHQRVQQRKESKKPPAKLQPR- } & (28) \\ \text { GSSFLSPEHQKAQQRKESKKPPAKLQPR- } & (28) \\ \text { GSSFLSPEHQKL-QRKEAKKPSGRLKPR- } & (27) \\ \text { GSSFLSPEHQKVQQRKESKKPAAKLKPR- } & (28) \\ \text { GSSFLSPEHQKLQQRKESKKPPAKLQPR- } & (28) \\ * \quad * * * * & \end{array}$

Figure 4 Comparison of amino acid sequence of ghrelin. *Amino acids that are identical in all species. Numbers in parentheses at right are number of amino acids. Amino acid sequences are available from the DDBJ/EMBL/GenBank databases (accession numbers AB062427 (eel), AF454389 (goldfish), AB058510 (bullfrog), AB075215 (chicken), AB029434 (human), AB092433 (rat), AB03571 (mouse), AF350329 (bovine), AF308930 (pig) and AJ298295 (dog)).

theoretical mass calculated from the 21-residue eel ghrelin sequence $(2295 \cdot 5 \mathrm{Da})$. These findings indicate that the $\mathrm{Ser}^{3}$ hydroxyl groups of peak I and II peptide are modified by $n$-octanoic acid or $n$-decanoic acid respectively. The structures determined for the eel ghrelin isoforms are shown in Fig. 3. We designated these two peptides as eel ghrelin-21 and eel ghrelin-21-C10, respectively. Amino acid sequences of various ghrelins determined so far are shown in Fig. 4. The first seven amino acids of eel ghrelin exhibit $100 \%$ sequence homology to those of mammalian ghrelins.

\section{Tissue expression of eel ghrelin $m R N A$}

A strong signal derived from ghrelin mRNA (approximately $0.5 \mathrm{~kb}$ ) was detected only in the stomach by northern blot analysis (Fig. 5a). RT-PCR with 30 cycles of amplification detected expression of ghrelin gene in the anterior intestine, outside the stomach (Fig. 5b, top). 
(a)

(b)

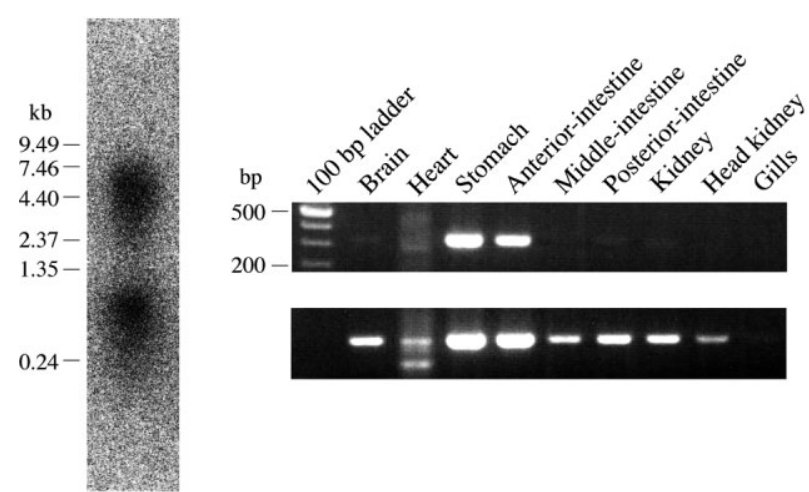

Figure 5 Gene expression analyses of eel ghrelin in various tissues. (a) Northern blot analysis. A hybridized signal (approximately $0.5 \mathrm{~kb}$ ) was detected only in the stomach. (b) RT-PCR analysis: top panel, result of 30 cycles of amplification; bottom panel, result of 35 cycles of amplification. Poly $(A)^{+}$RNA (50 ng) was subjected to reverse transcription, and one-fifth of the resulting cDNA was used as a template for specific amplification (305-bp product). Each lane contains three-quarters of the reaction mixture.

When the amplification cycle was increased to 35 cycles, gene expression was detected in the brain, heart, intestines, body kidney and head kidney, but not in the gill (Fig. 5b, bottom).

\section{Biological activity of eel ghrelin}

We examined the potency of eel ghrelin at the rat GHS-R using GHSR 62 cells. Administration of $0 \cdot 1-1000 \mathrm{nM}$ eel ghrelin-21 dose-dependently increased $\left[\mathrm{Ca}^{2+}\right]_{\mathrm{i}}$, with a potency similar to that of rat ghrelin, a full agonist for the GHS-R (Fig. 6a). Furthermore, eel and rat ghrelin elicited a similar level and pattern of release of $\mathrm{GH}$ in the rat, despite the considerable difference in the sequence between the two peptides (Fig. 6b). Plasma GH concentrations increased $5 \mathrm{~min}$ after intravenous injection of ghrelin, reaching a maximum at $10 \mathrm{~min}$ and returning to initial values at $60 \mathrm{~min}$.

To examine whether ghrelin stimulates the release of $\mathrm{GH}$ in fish, we used a bioassay system of organ-cultured whole pituitaries from tilapia. Release of PRL was also measured to determine the specificity of the effect of ghrelin on the release of GH. Eel ghrelin-21 stimulated the release of $\mathrm{GH}$ from the cultured tilapia pituitary (Fig. $7 a)$. Significant stimulation was observed at concentrations of 1 and $10 \mathrm{nM}$ up to $8 \mathrm{~h}$ after treatment. Ghrelin at $0 \cdot 1 \mathrm{nM}$ was without effect at $4 \mathrm{~h}$, but did elicit some activity after $8 \mathrm{~h}$. The effect of GH release was significantly $(P<0 \cdot 05)$ dose-dependent during the experimental period. Eel ghrelin was also effective in stimulating the release of PRL at all concentrations examined and at all time points (Fig. 7b). No dose-response relationship was (a)

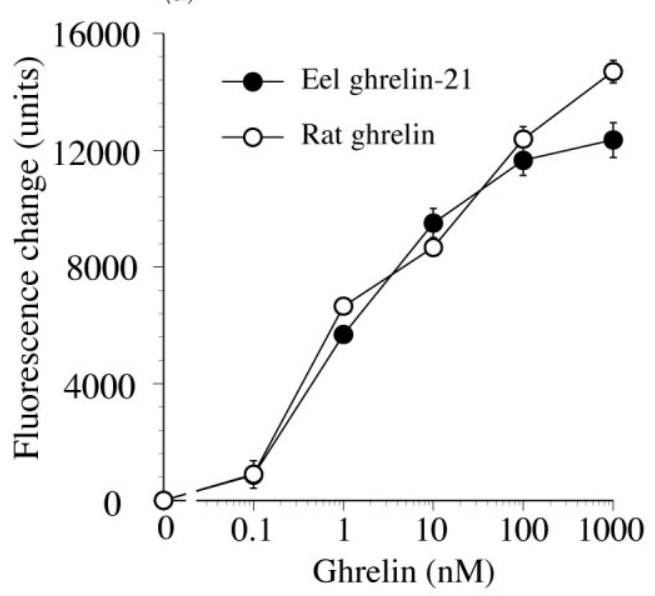

(b)

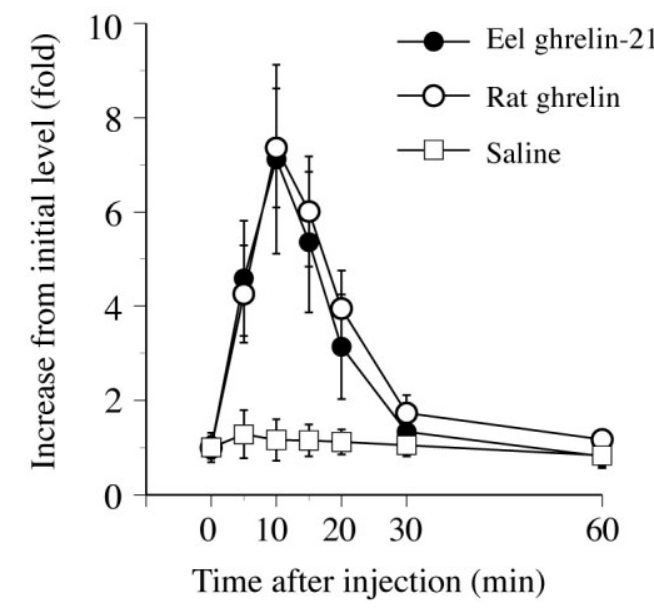

Figure 6 Biological activity of eel ghrelin in rat models. (a) Dose-response relationships of change in intracellular calcium concentrations in response to eel and rat ghrelins in CHO-GHSR62 cells. The maximum value of the response was used for calculation of the data. Values represent means \pm S.E.M. $(n=3)$. (b) Time-course of changes in plasma GH concentration after intravenous injection of eel ghrelin-21 or rat ghrelin into male Sprague-Dawley rats. Because of variation in the initial baseline concentrations, values (means \pm S.E.M., $n=5$ ) are expressed in terms of the ratio of each time point to the initial concentration (eel ghrelin, $145 \cdot 1 \pm 34 \cdot 3 \mathrm{ng} / \mathrm{ml}$; rat ghrelin, $118 \cdot 8 \pm 19 \cdot 1 \mathrm{ng} / \mathrm{ml}$; saline, $201 \cdot 9 \pm 62 \cdot 4 \mathrm{ng} / \mathrm{ml})$.

observed, however, which may suggest that the lowest concentration $(0 \cdot 1 \mathrm{nM})$ was sufficient to saturate the response.

\section{Discussion}

This paper describes the purification of ghrelin peptides from the stomach of a teleost fish, the Japanese eel. Ghrelin has also been cloned from the brain and intestine of 


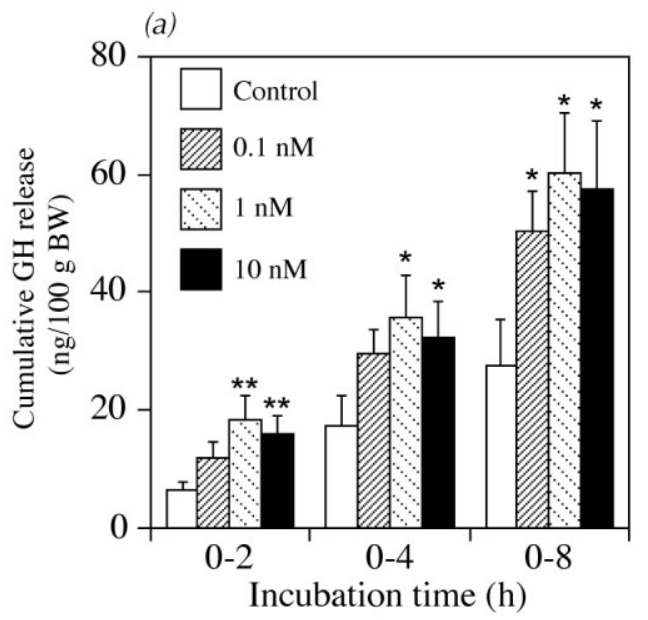

(b)

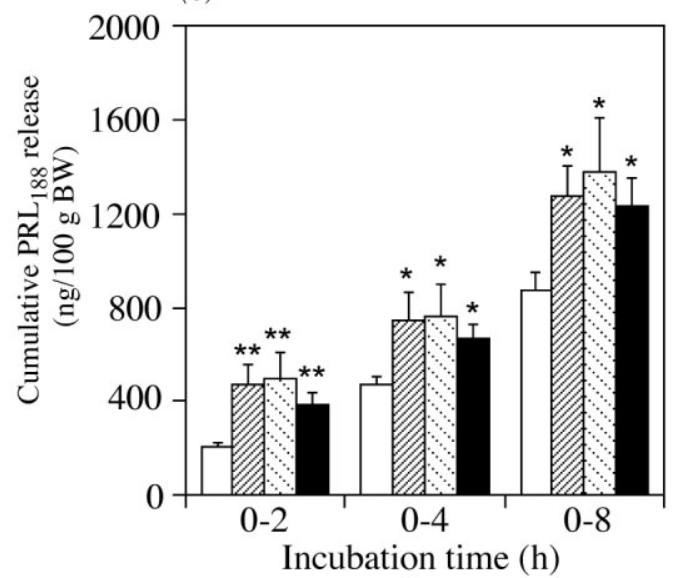

Figure 7 Effect of eel ghrelin on release of (a) growth hormone $(\mathrm{GH})$ and $(b)$ prolactin (PRL) from tilapia pituitary in vitro. Values are expressed as means \pm S.E.M. $(n=8)$. Significant difference at each time point were evaluated by least significant test or Mann-Whitney $U$-test. ${ }^{*} P<0 \cdot 05,{ }^{* *} P<0 \cdot 01$ compared with control.

goldfish (Unniappan et al. 2002). Eel ghrelin was capable of stimulating the release of $\mathrm{GH}$, a typical biological activity of ghrelin, in the rat both in vivo and in in vitro bioassay using cultured pituitaries of the tilapia. These findings support recent observations showing that the release of GH is regulated by a ghrelin-GHS-R system in fish (Palyha et al. 2000, Shepherd et al. 2000, Riley et al. 2002).

The $\mathrm{Ser}^{3}$ hydroxyl group of all of known mammalian ghrelins is acylated with n-octanoic acid (Kojima et al. 1999). Des-acyl ghrelin, which lacks the acyl modification, has no effect on $\left[\mathrm{Ca}^{2+}\right]_{i}$ in CHO-GHSR62 cells (Kojima et al. 1999) and does not bind to the GHS receptor (Muccioli et al. 2001). This acylation, therefore, is essential for ghrelin activity. Similarly, the $\mathrm{Ser}^{3}$ residue of eel ghrelin is also octanoylated, indicating that this modification is likely to be a conserved characteristic for receptor binding of ghrelin in many other vertebrates. A recently identified chicken ghrelin also has the same modification of the $\mathrm{Ser}^{3}$ residue (Kaiya et al. 2002). Although the acylated amino acid in bullfrog ghrelin is a Thr, not a Ser, it contains a hydroxyl group in the side chain, allowing octanoylation to occur (Kaiya et al. 2001).

In addition to the $n$-octanoylated form, we also isolated an eel ghrelin acylated with $n$-decanoic acid. Decanoylated ghrelin has been identified in the bullfrog (Kaiya et al. 2001) and human (Hosoda et al. 2002), but not in the rat (H. Hosoda et al., unpublished observation). In human, $25 \%$ of ghrelin isolated from the stomach is decanoylated. In the bullfrog, the decanoylated form represented 33\% of total isolated ghrelin. In the case of eel, $44 \%$ of the total ghrelin isolated was the decanoylated form. It is noteworthy that the percentage of the decanoylated form tends to increase in lower classes of vertebrates, although the mechanisms governing the acylation of ghrelin remain unknown. We did not test whether eel ghrelin-21-C10 is biologically active; the decanoylated form of ghrelin is biologically active in the rat and bullfrog, and its efficacy was similar to that of the octanoylated form (Matsumoto et al. 2001, Kaiya et al. 2001).

The complete amino acid sequence of eel ghrelin has only $46-48 \%$ identity to those of mammalian ghrelins. The first seven amino acids of eel ghrelin (GSSFLSP), however, exhibit 100\% sequence homology to both mammalian and chicken ghrelins. Nevertheless, eel ghrelin-21 showed the same potency as rat ghrelin with respect to GH-releasing activity and increase in intracellular calcium in rat models. A similar level of inter-species cross-activity was also seen with chicken ghrelin (Kaiya et al. 2002). In contrast, bullfrog ghrelin did not alter plasma GH concentrations in rats and showed only low affinity to rat GHS-R, but potently stimulated the releaseof GH and PRL from bullfrog pituitary cells (Kaiya et al. 2001). These differences in biological activity of ghrelin could be explained, in part, by species-specific binding of ghrelin to the GHS receptor for the animal. The N-terminal tetrapeptide (GSSF), including acyl modifications, is the 'active core' of ghrelin (Bednarek et al. 2000, Matsumoto et al. 2001). The active core of human, rat, chicken and eel ghrelins is 100\% identical, but bullfrog ghrelin contains two amino acid substitutions, to $\mathrm{Leu}^{2}-\mathrm{Thr}^{3}$ from $\mathrm{Ser}^{2}-\mathrm{Ser}^{3}$, in the active core. Thus the structure of the ligand-binding site of the GHS-R is likely to be similar in mammals, birds and fish (Palyha et al. 2000). It is noteworthy that recently identified goldfish ghrelin has one substitution in the region, from serine to threonine in the second amino acid (Unniappan et al. 2002).

Eel ghrelin possesses a unique amide structure at the C-terminal end. This structure was first identified in goldfish ghrelin (Unniappan et al. 2002). Mature eel ghrelin is produced by a typical amidation signal (GlyArg-Arg) at the C-terminal end. The dibasic processing 
signal (Arg-Arg) is conserved in non-mammalian vertebrates, including chicken (Kaiya et al. 2002), bullfrog (Kaiya et al. 2001) and goldfish (Unniappan et al. 2002). Amidation for the C-terminal carboxyl group of ghrelin fragments enhances ghrelin activity (Matsumoto et al. 2001). In the present study, however, the potency of eel ghrelin for release of $\mathrm{GH}$ in the rat was the same as that of rat ghrelin. Furthermore, non-amidated rat ghrelin stimulates the release of $\mathrm{GH}$ from fish pituitary (Riley et al. 2002). It is likely that the C-terminal amide structure does not affect receptor binding and activity of ghrelin. The physiological significance of the C-terminal amidation of ghrelin in fish, in addition to the diversity of the C-terminal amino acid sequence, remains to be elucidated.

To evaluate the effect of eel ghrelin on the release of $\mathrm{GH}$ in fish, we used organ-cultured tilapia pituitaries, because a homologous radioimmunoassay for eel GH is not currently available. We have reported earlier that intraperitoneal injection of a GHS, KP-102, significantly increased plasma GH concentrations in the tilapia, suggesting that a specific GHS receptor is present in the tilapia (Shepherd et al. 2000). Recently, we have shown that rat ghrelin stimulates the release of $\mathrm{GH}$ from cultured tilapia pituitaries (Riley et al. 2002). In the present study, eel ghrelin stimulated the release of GH from tilapia pituitaries, indicating that eel ghrelin is capable of stimulating $\mathrm{GH}$ release in fish by acting directly on the pituitary. The release of GH from the pituitary increased twofold above control levels. A similar response was observed when rat pituitary cells were exposed to ghrelin (Kojima et al. 1999). In contrast, the in vivo response of $\mathrm{GH}$ release in the rat was sevenfold, compared with a threefold increase in vitro. In the rat, Date et al. (2002) have recently reported that the gastric vagal afferent is the major pathway conveying the ghrelin signal for GH release to the brain. This finding suggests that intermediate factor(s) may modify the signal of peripheral ghrelin.

In addition to $\mathrm{GH}$ release, PRL secretion was also stimulated by eel ghrelin in the tilapia pituitary. We have also shown that rat ghrelin stimulated the release of PRL from the tilapia pituitary (Riley et al. 2002). PRLreleasing activity of ghrelin has been observed in bullfrog pituitary cells (Kaiya et al. 2001). In contrast, no increase in PRL was observed in dispersed rat pituitary cells (Kojima et al. 1999). These results suggest a speciesspecific effect of ghrelin on PRL cells in lower vertebrates.

Ghrelin in the eel is synthesized predominantly in the stomach. This is in agreement with findings in other animals (Kojima et al. 1999, Kaiya et al. 2001, 2002). In the eel, relatively high expression of ghrelin gene was also observed in the anterior intestine by RT-PCR analysis. This was also observed in the goldfish (Unniappan et al. 2002). It is to be noted that goldfish lack a stomach, and therefore the intestine may be the primary site of ghrelin production. Furthermore, ghrelin mRNA was detected in the brain, heart, intestines, kidney and head kidney of the eel. These results are slightly different from that in the goldfish (Unniappan et al. 2002). The physiological significance of gene expression in the various tissues remains unknown, but brain-derived ghrelin seems to be involved in feeding, as seen in the goldfish.

In conclusion, we have shown that ghrelin is present in the eel stomach, stimulating the release of $\mathrm{GH}$ and PRL from the pituitary. Thus the regulatory function of pituitary activity by ghrelin through a novel gastropituitary pathway seems to be conserved in vertebrates, including fish, amphibians, avians and mammals. In fish, stimulation of GH secretion is controlled by various hypothalamic neuropeptides (Peng \& Peter 1997, Montero et al. 2000), and gastric or brain-derived ghrelin could also be a primary regulator of $\mathrm{GH}$ release.

\section{Acknowledgements}

The nucleotide sequence for the eel ghrelin precursor has been deposited in the DDBJ/EMBL/GenBank databases with the accession number AB062427.

We thank Yasuo Kitajima, Masaru Matsumoto and Yoshiharu Minamitake at the Suntory Institute for Medicinal Research and Development for synthesizing eel ghrelin peptides.

This work was supported in part by a Grant-in-Aid for Scientific Research from the MEXT of Japan, the Promotion of Fundamental Studies in Health Science from the Organization for Pharmaceutical Safety and Research (OPSR) of Japan, a grant from Takeda Science Foundation, and also by grants from the National Science Foundation (IBN 01-33714), US Department of Agriculture (No. 9835206644) and University of Hawaii Sea Grant College Program (NOAA project R/AQ-62, Institutional Grant No. NA86RG0041, UNIHI-SEAGRANT-JC-01-12).

\section{References}

Ayson FG, Kaneko T, Tagawa M, Hasegawa S, Grau EG, Nishioka RS, King DS, Bern HA \& Hirano T 1993 Effects of acclimation to hypertonic environment on plasma and pituitary levels of two prolactins and growth hormone in two species of tilapia Oreochromis mossambicus and Oreochromis niloticus. General and Comparative Endocrinology 89 138-148.

Bednarek MA, Feighner SD, Pong SS, McKee KK, Hreniuk DL, Silva MV, Warren VA, Howard AD, Van Der Ploeg LH \& Heck JV 2000 Structure-function studies on the new growth hormonereleasing peptide, ghrelin: minimal sequence of ghrelin necessary for activation of growth hormone secretagogue receptor 1a. Journal of Medicinal Chemistry 43 4370-4376.

Blaise O, Le Bail P-Y \& Weil C 1995 Lack of gonadotropin releasing-hormone action on in vitro and in vivo growth hormone release in rainbow trout (Oncorhynchus mykiss). Comparative Biochemistry and Physiology C 110 133-141. 
Bluet-Pajot MT, Epelbaum J, Gourdji D, Hammond C \& Kordon C 1998 Hypothalamic and hypophyseal regulation of growth hormone secretion. Cellular and Molecular Neurobiology 18 101-123.

Bosma PT, Kolk SM, Rebers FE, Lescroart O, Roelants I, Willems PH \& Schulz RW 1997 Gonadotrophs but not somatotrophs carry gonadotrophin-releasing hormone receptors: receptor localisation, intracellular calcium, and gonadotrophin and GH release. Journal of Endocrinology 152 437-446.

Date Y, Murakami N, Toshinai K, Matsukura S, Niijima A, Matsuo H, Kangawa K \& Nakazato M 2002 The role of the gastric afferent vagal nerve in ghrelin-induced feeding and growth hormone secretion in rats. Gastroenterology 123 1120-1128.

Eckert SM, Hirano T, Leedom TA, Takei Y \& Grau EG 2002 Effects of angiotensin II and natriuretic peptides on prolactin and growth hormone release in the tilapia, Oreochromis mossambicus. General and Comparative Endocrinology (In Press).

Hosoda H, Kojima M, Mizushima T, Shimizu S \& Kangawa K 2002 Structural divergence of human ghrelin; identification of multiple ghrelin-derived molecules produced by post-transcriptional processing. Journal of Biological Chemistry (In Press).

Kaiya H, Kojima M, Hosoda H, Koda A, Yamamoto K, Kitajima Y, Matsumoto M, Minamitake Y, Kikuyama S \& Kangawa K 2001 Bullfrog ghrelin is modified by $n$-octanoic acid at its third threonine residue. Journal of Biological Chemistry 276 40441-40448.

Kaiya H, Van Der Geyten S, Kojima M, Hosoda H, Kitajima Y, Matsumoto M, Geelissen S, Darras VM \& Kangawa K 2002 Chicken ghrelin: purification, cDNA cloning and biological activity. Endocrinology 143 3454-3463.

Kojima M, Hosoda H, Date Y, Nakazato M, Matsuo H \& Kangawa K 1999 Ghrelin is a growth-hormone-releasing acylated peptide from stomach. Nature 402 656-660.

Matsumoto M, Hosoda H, Kitajima Y, Morozumi N, Minamitake Y, Tanaka S, Matsuo H, Kojima M, Hayashi Y \& Kangawa K 2001 Structure-activity relationship of ghrelin: pharmacological study of ghrelin peptides. Biochemical and Biophysical Research Communication 287 142-146.

Melamed P, Eliahu N, Levavi-Sivan B, Ofir M, Farchi-Pisanty O, Pentier-Delerue F, Smal J, Yaron Z \& Naor Z 1995 Hypothalamic and thyroidal regulation of growth hormone in tilapia. General and Comparative Endocrinology 97 13-30.

Montero M, Yon L, Rousseau K, Arimura A, Fournier A, Dufour S \& Vaudry H 1998 Distribution, characterization, and growth hormone-releasing activity of pituitary adenylate cyclase-activating polypeptide in the European eel, Anguilla anguilla. Endocrinology 139 4300-4310.

Montero M, Yon L, Kikuyama S, Dufour S \& Vaudry H 2000 Molecular evolution of the growth hormone-releasing hormone/pituitary adenylate cyclase-activating polypeptide gene family. Functional implication in the regulation of growth hormone. Journal of Molecular Endocrinology 25 157-168.

Muccioli G, Papotti M, Locatelli V, Ghigo E \& Deghenghi R 2001 Binding of ${ }^{125}$ I-labeled ghrelin to membranes from human hypothalamus and pituitary gland. Journal of Endocrinolgical Investigation 24 RC7-RC9.

Palyha OC, Feighner SD, Tan CP, McKee KK, Hreniuk DL, Gao YD, Schleim KD, Yang L, Morriello GJ, Nargund R, Patchett AA, Howard AD \& Smith RG 2000 Ligand activation domain of human orphan growth hormone $(\mathrm{GH})$ secretagogue receptor (GHS-R) conserved from pufferfish to human. Molecular Endocrinology 14 160-169.

Parker DB, Power ME, Swanson P, Rivier J \& Sherwood NM 1997 Exon skipping in the gene encoding pituitary adenylate cyclaseactivating polypeptide in salmon alters the expression of two hormones that stimulate growth hormone release. Endocrinology 138 414-423.

Peng C \& Peter RE 1997 Neuroendocrine regulation of growth hormone secretion and growth in fish. Zoological Studies 36 79-89.

Riley LG, Hirano T \& Grau EG 2002 Rat ghrelin stimulates growth hormone and prolactin release in the tilapia, Oreochromis mossambicus. Zoological Science 19 797-800.

Rousseau K, Le Belle N, Marchelidon J \& Dufour S 1999 Evidence that corticotropin-releasing hormone acts as a growth hormone-releasing factor in a primitive teleost, the European eel (Anguilla anguilla). Journal of Neuroendocrinology 11 385-392.

Shepherd BS, Eckert SM, Parhar IS, Vijayan MM, Wakabayashi I, Hirano T, Grau EG \& Chen TT 2000 The hexapeptide KP-102 (D-Ala-D- $\beta-\mathrm{Nal}-\mathrm{Ala}-\mathrm{Trp}-\mathrm{D}-\mathrm{Phe}-\mathrm{Lys}-\mathrm{NH}_{2}$ ) stimulates growth hormone release in a cichlid fish (Oreochromis mossambicus). Journal of Endocrinology 167 R7-R10.

Unniappan S, Lin X, Cervini L, Rivier J, Kaiya H, Kangawa K \& Peter RE 2002 Goldfish ghrelin: molecular characterization of the complementary deoxyribonucleic acid, partial gene structure and evidence for its stimulatory role in food intake. Endocrinology 143 4143-4146.

Wigham T, Nishioka RS \& Bern HA 1977 Factors affecting in vitro activity of prolactin cells in the euryhaline teleost Sarotherodin mossambicus (Tilapia mossambicus). General and Comparative Endocrinology 32 120-131.

Yada T, Hirano T \& Grau EG 1994 Changes in plasma levels of the two prolactins and growth hormone during adaptation to different salinities in the euryhaline tilapia, Oreochromis mossambicus. General and Comparative Endocrinology 93 2214-2223.

Received 10 September 2002

Accepted 11 November 2002 